\title{
HUBUNGAN KADAR HEMOGLOBIN IBU DAN LETAK JANIN DENGAN KEJADIAN KETUBAN PECAH DINI DI KLINIK ALISA TALANG KRAMAT KENTEN TAHUN 2018
}

\author{
Desi Hariani \\ STIK Siti Khadijah Palembang
}

\author{
Informasi Artikel : \\ Diterima : $\quad$ Maret 2019 \\ Disetujui : Juni 2019
}

"Korespondensi Penulis :

desinetra@yahoo.com

\begin{abstract}
A B S T R A K
Ketuban pecah dini adalah pecahnya selaput ketuban pada setiap saat sebelum permulaan persalinan tanpa memandang apakah pecahnya selaput ketuban terjadi pada kehamilan 24 minggu atau 44 minggu. Kadar hemoglobin adalah ukuran pigmen respiratorik dalam butiran-butiran darah merah. Kelainan letak janin merupakan malpresentasi janin atau kelainan letak janin yang dapat membuat ketuban bagian terendah langsung menerima tekanan intra uteri yang dominan. Tujuan penelitian ini adalah mengetahui hubungan kadar hemoglobin ibu dan letak janin dengan kejadian ketuban pecah dini di klinik alisa talang keramat kenten Palembang Tahun 2018. Desain penelitian ini menggunakan metode survey analitik dengan pendekatan crossectional. Sampel berjumlah 63 orang. Pengambilan menggunakan teknik total sampling. Pengumpulan data menggunakan lembar checklist.Hasil analisis univariat didapatkan jumlah ibu yang mengalami ketuban pecah dini $(22,3 \%)$, HB tidak normal $(41,3 \%)$ dan letak sungsang $(6,3 \%)$. Dari hasil analisis bivariat dengan uji statistik Chi - Square ada hubungan bermakna antara kadar hemoglobin ibu $p$ value $=0,001$ $<\alpha 0,05$ nilai $\mathrm{OR}=0,049$ dan letak janin $p$ value $=0,001<\alpha 0,05$ nilai $\mathrm{OR}=0,032$ dengan kejadian ketuban pecah dini secara statistik terbukti. Melalui penelitian ini, diharapkan dapat memberikan pelayanan kesehatan yang lebih baik lagi pada ibu hamil dan bersalin sehingga tidak terjadi komplikasi.
\end{abstract}

Kata Kunci : Ketuban Pecah Dini, Kadar Hemoglobin, Letak Janin

\section{ABSTRACT}

Premature rupture of membranes isthe rupture of the membranes at any time before the onset of labor, regardless of whether the rupture of the membranes occurs at 24 weeks or 44 weeks' gestation. Hemoglobin levels are the size of respiratory pigments in red blood granules. Fetal abnormalities are malpresentations of fetuses or fetal abnormalities that can make the lowest part of the membrane directly accept the dominant intrauterine pressure. The aim of this study is to know the correlation between maternal hemoglobin level and fetal location toward the incidence of premature rupture of membranes at klinik alisa talang keramat kenten The study design using analytical survey method with crossectional approach. The sample numbered 63 people. Taking by using total sampling technique. Data collection using checklist sheet. The result of univariate analysis showed that the number of mothers who had membranes rupturedearly was (22.3\%), HB was not normal (41.3\%) and breech position was (6.3\%). From bivariate analysis with Chi-Square statistical test there was a significant correlation between maternal hemoglobin level $p$ value $=0.001<\alpha 0.05$ value $O R=0.049$ and fetal location $p$ value $=$ $0.001<\alpha 0.05$ value $O R=0.032$ with incidence of premature 
rupture of membranes was statistically proven. Through this research, it is expected to provide better health services in pregnant and maternity women so thereis no complications occur.

Key word : Premature rupture of membranes, Hemoglobin levels, Fetal Location

\section{PENDAHULUAN}

Ketuban pecah dini (KPD) merupakan masalah yang masih banyak terjadi dalam kebidanan. Banyak faktor yang menyebabkan KPD antara lain letak janin, preeklampsia, anemia, kadar hemoglobin, gemelli dan hidramnion. Faktor tersebut merupakan faktor yang menjadi penyebab kematian ibu dan kematian bayi (Huda, 2016).

Menurut World Health Organization (WHO) memperkirakan 800 perempuan meninggal setiap harinya akibat komplikasi kehamilan dan proses kelahiran. Sekitar 99\% dari seluruh kematian ibu terjadi di negara berkembang. Sekitar $80 \%$ kematian maternal merupakan akibat meningkatnya komplikasi selama kehamilan, persalinan dan setelah persalinan (WHO, 2014).

Berdasarkan Survei Demografi dan Kesehatan Indonesia (SDKI), pada tahun 1990, AKI di Indonesia 390 per 100.000 kelahiran hidup. Pada tahun 2007, AKI di Indonesia 228 per 100.000 kelahiran hidup. Pada tahun 2013 di Indonesia rasio kematian ibu sebesar 190 kematian ibu per 100.000 kelahiran bayi hidup. Beberapa penyebab kematian ibu secara lansung diantaranya perdarahan $30 \%$, sklampsia $25 \%$, infeksi $12 \%$, abortus 5\%, emboli obstetri 3\%, komplikasi masa nifas $16 \%$, penyebab lainnya $12 \%$. Sedangkan penyebab tidak lansung lainnya seperti terlambat mengenali tanda bahaya karena tidak mengetahui tanda kehamilan untuk mendapatkan pelayanan (Kemenkes, 2015).

Penyebab kematian ibu adalah komplikasi obstetrik, menurut DepKes RI (2013) menjelaskan sekitar 30\% kejadian pada ibu yang mengalami KPD di Indonesia adalah infeksi. Menurut SDKI kira-kira 90\% kematian ibu terjadi di saat persalinan. Angka kematian KPD cukup tinggi yaitu $30 \%$ dari 100 persalinan.

Berdasarkan data dari Bahan Pusat Statistik (BPS) Provinsi Sumatra Selatan, jumlah ibu bersalin yang ada di Sumatra Selatan tahun 2014 berjumlah 33.852 kelahiran hidup dengan PEB 21,4\%, perdarahan 16,2\%, KPD 25,4\%, DM 14\%. Pada tahun 2015 berjumlah 37.899 ibu bersalin, dengan PEB 25,1\%, perdarahan 10,2\%, KPD 26,8\%, DM 12,5\% (BPS, 2015).

Berdasarkan dari data Dinas Kesehatan Kota Palembang pada tahun 2016 jumlah ibu bersalin 30.421 sedangkan yang mengalami KPD 22,5\%. Pada tahun 2015 jumlah ibu bersalin 32.891 dan yang mengalami KPD 25,3\% (Dinkes, 2015).

Berdasarkan data dari klinik alisa talang keramat kenten Palembang Tahun 2018 sebanyak 97 persalinan dan yang mengalami ketuban pecah dini ada 16 orang ibu, dan pada tahun 2017 jumlah ibu yang melahirkan sebanyak 106 persalinan dan yang mengalami ketuban peacah dini ada 21 orang ibu, kejadian ini terus meningkat dari tahun ketahun. Pada tahun 2017 jumlah ibu yang melahirkan sebanyak 114 orang dan ada 34 orang ibu dengan kejadian KPD dan pada tahun 2018 (1 januari - 1 Juni) sebanyak 63 orang persalinan ada 14 orang ibu dengan kejadian KPD.

Dari uraian di atas maka penulis merasa tertarik untuk melakukan penelitian tentang "Hubungan kadar hemoglobin ibu dan letak janin dengan kejadian ketuban pecah dini di klinik alisa talang keramat kenten Palembang Tahun 2018.

\section{TINJAUAN PUSTAKA}

Ketuban Pecah Dini (KPD) adalah pecahnya selaput ketuban pada setiap saat sebelum permulaan persalinan tanpa memandang apakah pecahnya selaput ketuban terjadi pada kehamilan 24 minggu atau 44 minggu (Manuaba, 2008).

Kadar hemoglobin adalah ukuran pigmen respiratorik dalam butiran-butiran darah merah. Jumlah hemoglobin dalam darah normal kira-kira 15 gram setiap $100 \mathrm{ml}$ darah dan jumlah ini biasanya disebut "100 persen" (Evelyn, 2009).

Kelainan letak merupakan salah satu faktor penyebab ketuban pecah dini (KPD) karena kelainan letak ini mengakibatkan tidak ada bagian terendah yang menutupi pintu atas panggul (PAP) yang dapat menghalangi tekanan terhadap membran bagian bawah (Nugroho, 2012).

\section{METODE PENELITIAN}

Desain penelitian menggunakan metode survey analitik dengan menggunakan pendekatan "Cross Sectional" dimana variabel independen (kadar hemoglobin dan letak janin) dengan variabel dependen (ketuban pecah dini) akan 
dikumpulkan dalam waktu yang bersamaan (Notoatmodjo, 2012). Populasi yang diambil adalah adalah semua ibu bersalin di BPM klinik alisa pada bulan januari-juni talang keramat kenten Palembang Tahun 2018.

Teknik pengambilan sampel dalam penelitian ini menggunakan metode total sampling, artinya semua ibu bersalin yang berjumlah 63 orang dijadikan sebagai sampel. Waktu penelitian ini dilakukan pada Mei - Juni Tahun 2018. Tempat Penelitian ini dilakukan di klinik alisa talang keramat kenten Palembang.

\section{HASIL PENELITIAN}

Ketuban Pecah Dini

Berdasarkan hasil penelitian pada variabel ketuban pecah dini dibagi menjadi dua katagori yaitu: Ya (jika ibu terdiagnosis ketuban pecah dini) dan Tidak (jika ibu tidak terdiagnosis ketuban pecah dini). Dapat dilihat dari tabel 1 sebagai berikut :

Tabel 1 Distribusi Frekuensi Responden Berdasarkan Kejadian Ketuban Pecah Dini Di klinik alisa talang keramat kenten Palembang Tahun 2018

\begin{tabular}{ccc}
\hline $\begin{array}{c}\text { Ketuban } \\
\text { Pecah Dini }\end{array}$ & Jumlah & $\begin{array}{c}\text { Persentase } \\
(\%)\end{array}$ \\
\hline Ya & 14 & 22,2 \\
\hline Tidak & 19 & 77,8 \\
\hline Jumlah & 63 & 100 \\
\hline
\end{tabular}

Dari tabel diatas dapat dilihat bahwa dari 63 responden, yang mengalami ketuban pecah dini sebanyak 14 responden $(22,3 \%)$ dan yang tidak mengalami ketuban pecah dini sebanyak 49 responden $(77,8 \%)$.

\section{Kadar Hemoglobin}

Berdasarkan hasil penelitian pada variabel kadar hemoglobin, karakteristik kadar hemoglobin dibagi menjadi 2 katagori yaitu: Normal (jika HB > 11gr\%), Tidak Normal (jika $\mathrm{HB}<11 \mathrm{gr} \%)$. Dapat dilihat dari tabel 2 sebagai berikut :

Tabel 2 Distribusi Frekuensi Responden Berdasarkan Kadar Hemoglobin klinik alisa talang keramat kenten Palembang Tahun 2018

\begin{tabular}{ccc}
\hline Kadar Hemoglobin & Jumlah & $\begin{array}{c}\text { Persentase } \\
(\mathbf{\%})\end{array}$ \\
\hline Normal>11 gr\% & 31 & 49,2 \\
\hline Tidak Normal<11 gr\% & 32 & 50,8 \\
\hline Jumlah & 63 & 100 \\
\hline Dari tabel diatas dapat dilihat bahwa dari
\end{tabular}

63 responden, yang mengalami kadar hemoglobin Normal (jika HB > 11gr\%) sebanyak 31 responden $(49,2 \%)$, dan kadar hemoglobin Tidak Normal (jika $<11 \mathrm{gr} \%$ ) sebanyak 32 responden $(50,8 \%)$.

\section{Letak Janin}

Berdasarkan hasil penelitian pada variabel letak janin, karakteristik letak janin dibagi menjadi 2 katagori yaitu: Presentasi Kepala dan Letak Sungsang. Dapat dilihat dari tabel 3 sebagai berikut :

Tabel 3 Distribusi Frekuensi Responden Berdasarkan Letak Janin Di klinik alisa talang keramat kenten Palembang Tahun 2018

Letak Janin Jumlah Presentase (\%)

\begin{tabular}{ccc}
\hline Presentasi Kepala & 53 & 84,1 \\
Letak Sungsang & 10 & 15,9 \\
\hline Jumlah & 63 & 100 \\
\hline
\end{tabular}

Dari tabel diatas dapat dilihat bahwa dari 63 responden, yang lahir dengan prsentasi kepala sebanyak 53 responden $(87,3 \%)$, letak sungsang sebanyak 10 responden $(15,9 \%)$.

\section{Hubungan Antara Kadar Hemoglobin Dengan Kejadian Ketuban Pecah Dini}

Berdasarkan hasil penelitian hubungan antara kadar hemoglobin dengan kejadian ketuban pecah dini, karakteristik kadar hemoglobin dibagi menjadi 2 katagori yaitu: Normal (jika HB > 11 gr\%), Tidak Normal (jika HB < 11 gr\%). Dapat dilihat dari tabel 5.4 sebagai berikut :

Tabel 4 Hubungan Antara Kadar Hemoglobin dengan Kejadian Ketuban Pecah Dini Di klinik alisa talang keramat kenten Palembang Tahun 2018

\begin{tabular}{|c|c|c|c|c|c|}
\hline \multirow{3}{*}{$\begin{array}{c}\text { Kadar } \\
\text { Hemoglobin }\end{array}$} & \multicolumn{2}{|c|}{$\begin{array}{c}\text { Ketuban Pecah } \\
\text { Dini }\end{array}$} & \multirow[t]{2}{*}{ Total } & \multirow{2}{*}{$\begin{array}{c}\mathrm{P} \\
\text { value }\end{array}$} & \multirow[t]{2}{*}{ OR } \\
\hline & Ya & Tidak & & & \\
\hline & n \% & n $\%$ & $\%$ & \multirow{4}{*}{0,001} & \multirow{4}{*}{0,049} \\
\hline Normal & $1 \quad 7,1$ & $30 \quad 61,23$ & 49,2 & & \\
\hline Tidak Normal & 1392,9 & 1938,83 & 50,8 & & \\
\hline Jumlah & 14 & 49 & 100 & & \\
\hline \multicolumn{6}{|c|}{$\begin{array}{l}\text { Dari tabel diatas dapat dilihat bahwa dari } \\
31 \text { responden }(49,2 \%) \text { dengan kadar hemoglobin } \\
\text { normal yang mengalami ketuban pecah dini } \\
\text { sebanyak } 1 \text { responden }(7,1 \%) \text { sedangkan yang } \\
\text { tidak mengalami ketuban pecah dini sebanyak } 30 \\
\text { responden }(61,2 \%) \text {, dari } 32 \text { responden }(50,8 \%)\end{array}$} \\
\hline
\end{tabular}


dengan kadar hemoglobin tidak normal yang mengalami ketuban pecah dini sebanyak 13 responden $(92,9 \%)$ sedangkan yang tidak mengalami ketuban pecah dini sebanyak 19 responden $(38,8 \%)$. Hasil uji statistik dipeoleh $p$ value $=0,001<\alpha(0,05)$ maka dapat disimpulkan ada hubungan yang signifikan antara kadar hemoglobin dengan kejadian ketuban pecah dini.

Nilai OR $=0,049$ ini berarti kadar hemoglobin yang tidak normal cenderung untuk mengalami ketuban pecah dini sebesar 0,49 kali lebih besar jika dibandingkan dengan kadar hemoglobin normal.

\section{Hubungan Antara Letak Janin Dengan Kejadian Ketuban Pecah Dini}

Berdasarkan hasil penelitian hubungan antara letak janin dengan kejadian ketuban pecah dini, karakteristik letak janin dibagi menjadi 2 katagori yaitu: Presentase Kepala dan Letak Sungsang. Dapat dilihat dari tabel 5 sebagai berikut :

Tabel 5 Hubungan Antara Letak Janin dengan Kejadian Ketuban Pecah Dini Di klinik alisa talang keramat kenten Palembang Tahun 2018

\begin{tabular}{|c|c|c|c|c|c|c|}
\hline \multirow{3}{*}{ Letak janin } & \multicolumn{2}{|c|}{$\begin{array}{l}\text { Ketuban } \\
\text { Pecah Dini }\end{array}$} & \multirow{2}{*}{\multicolumn{2}{|c|}{ Total }} & \multirow{3}{*}{$\begin{array}{c}\mathrm{P} \\
\text { value }\end{array}$} & \multirow[t]{2}{*}{$\mathbf{O R}$} \\
\hline & $\mathrm{Ya}$ & Tidak & & & & \\
\hline & $\mathrm{n} \%$ & $\mathrm{n} \%$ & $\mathrm{n}$ & $\%$ & & \\
\hline Persentasi Kepala & 642,9 & 4795,9 & 53 & 84,1 & & \\
\hline Letak Sungsang & 857,1 & 24,1 & 10 & 15,9 & & 0,032 \\
\hline Jumlah & 14 & 49 & 63 & 100 & & \\
\hline
\end{tabular}

Dari tabel diatas dapat dilihat dari 53 responden $(84,1 \%)$ dengan presentasi kepala yang mengalami ketuban pecah dini sebanyak 6 responden $(42,9 \%)$ sedangkan yang tidak mengalami ketuban pecah dini sebanyak 47 responden $(95,9 \%)$, dari 10 responden $(15,9 \%)$ dengan letak sungsang yang mengalami ketuban pecah dini sebanyak 8 responden $(57,1 \%)$ sedangkan yang tidak mengalami ketuban pecah dini sebanyak 2 responden $(4,1 \%)$. Hasil uji statistik diperoleh $p$ value $=0,001<\alpha(0,05)$, maka dapat disimpulkan ada hubungan yang signifikan antara letak janin dengan kejadian ketuban pecah dini.

Nilai OR $=0,032$ ini berarti letak sungsang cenderung untuk mengalami ketuban pecah dini sebesar 0,032 kali lebih besar jika dibandingkan dengan presentasi kepala.

\section{PEMBAHASAN}

Hubungan Antara Kadar Hemoglobin Dengan Kejadian Ketuban Pecah Dini

Berdasarkan hasil penelitian pada variabel kadar hemoglobin dilakukakan terhadap 63 sampel, karakteristik kadar hemoglobin dibagi menjadi 2 katagori yaitu: Normal (jika HB > 11 gr\%), Tidak Normal (jika HB < 11 gr\%). Dari hasil univariat diketahui jumlah dari 63 responden menunjukkan bahwa yang mengalami kadar hemoglobin Normal (jika HB > 11 gr\%) sebanyak 31 responden $(49,2 \%)$, dan kadar hemoglobin Tidak Normal (jika < 11 gr\%) sebanyak 32 responden $(50,8 \%)$.

Hasil analisis bivariat hubungan antara kadar hemoglobin dengan kejadian ketuban pecah dini di klinik alisa talang keramat kenten Palembang Tahun 2018 terhadap 63 responden, dapat dilihat bahwa dari 31 responden $(49,2 \%)$ dengan kadar hemoglobin normal yang mengalami ketuban pecah dini sebanyak 1 responden $(7,1 \%)$ sedangkan yang tidak mengalami ketuban pecah dini sebanyak 30 responden $(61,2 \%)$, dari 32 responden $(50,8 \%)$ dengan kadar hemoglobin tidak normal yang mengalami ketuban pecah dini sebanyak 13 responden $(92,9 \%)$ sedangkan yang tidak mengalami ketuban pecah dini sebanyak 19 responden $(38,8 \%)$.

Hasil uji Chi-Square menunjukan $p$ value $=0,001<\alpha(0,05)$ dan nilai $\mathrm{OR}=0,049$. Hal ini menunjukkan ada hubungan yang bermakna antara kadar hemoglobin ibu dengan kejadian ketuban pecah dini di klinik alisa talang keramat kenten Palembang Tahun 2018. Sehingga, hipotesis yang menyatakan ada hubungan antara kadar hemoglobin dengan kejadian ketuban pecah dini terbukti secara statistik.

Menurut Ritawati (2009) mengungkapkan bahwa kadar hemoglobin yang rendah kurang dari 11,1 gr\% selama kehamilan diduga sebagai penyebab tanpa diserta gejala yang menyebabkan terjadinya infeksi dan pada akhirnya meningkatkan kejadian KPD pada kehamilan prematur.

Hasil penelitian ini sejalan dengan hasil penelitian Sudarto (2015) dengan judul Hubungan Anemia Dengan Kejadian Ketuban Pecah Dini Di Rumah Sakit Umum Santo Antonius Pontianak didapatkan hasil pengujian statistik menggunakan Chi-Square menunjukkan ada hubungan yang bermakna antara anemia dengan kejadian ketuban pecah dini dengan $(\mathrm{p}=0,000$ dan $\mathrm{OR}=7,78)$. Sehingga hipotetsis yang menyatakan ada hubungan antara kadar 
hemoglobin dengan kejadian ketuban pecah dini terbukti secara statistik.

Dari hasil penelitian, teori terkait dan penelitian terkait sejalan dengan penelitian yang saya lakukan di klinik alisa talang keramat kenten Palembang Tahun 2018 menunjukkan sebagian besar sampel mengalami kadar hemoglobin yang tidak normal $(<11$ gr\%) dengan kejadian ketuban pecah dini. Hal ini tejadi karena kadar hemoglobin dapat mempengaruhi kekuatan respon tubuh terhadap infeksi dan fungsi imun yang mengakibatkan penurunan kemampuan sel pembuluh darah. Sehingga dapat disimpulkan bahwa ada hubungan kadar hemoglobin dengan kejadian ketuban pecah dini.

\section{Hubungan Antara Letak Janin Dengan Kejadian Ketuban Pecah Dini}

Berdasarkan hasil penelitian pada variabel letak janin dilakukan terhadap 63 sampel, karakteristik letak janin dibagi menjadi 2 kategori, yaitu : presentasi kepala dan letak sungsang. Dari hasil univariat diketahui jumlah dari 63 responden menunjukkan bahwa yang lahir dengan persentasi kepala sebanyak 53 responden $(87,3 \%)$, letak sungsang sebanyak 10 responden $(15,9 \%)$.

Hasil analisis bivariat hubungan antara letak janin dengan kejadian ketuban pecah dini di klinik alisa talang keramat kenten Palembang Tahun 2018 terhadap 63 responden, dapat dilihat dari 53 responden $(84,1 \%)$ dengan presentasi kepala yang mengalami ketuban pecah dini sebanyak 6 responden $(42,9 \%)$ sedangkan yang tidak mengalami ketuban pecah dini sebanyak 47 responden $(95,9 \%)$, dari 10 responden $(15,9 \%)$ dengan letak sungsang yang mengalami ketuban pecah dini sebanyak 8 responden $(57,1 \%)$ sedangkan yang tidak mengalami ketuban pecah dini sebanyak 2 responden $(4,1 \%)$.

Hasil uji statistik diperoleh $p$ value $=0,001$ $<\alpha(0,05)$ dan nilai OR $=0,032$. Hal ini menunjukkan ada hubungan yang bermakna antara letak janin dengan kejadian ketuban pecah dini di klinik alisa talang keramat kenten Palembang Tahun 2018. Sehingga, hipotesis yang menyatakan ada hubungan antara letak janin dengan kejadian ketuban pecah dini terbukti secara statistik.

Menurut Hartono (2009) mengungkapkan bayi dengan letak sungsang akan merusak lapisan ketuban karena janin memanjang dengan kepala di fundus uteri dan bokong di bagian bawah kavum uteri sehingga ketuban sering pecah sebelum waktunya. Hasil penelitian menunjukkan sebanyak 45\% ibu hamil dengan bayi letak sungsang mengalami ketuban pecah dini (KPD) pada saat persalinan.

Hasil penelitian ini sejalan dengan hasil penelitian Sugiarti (2015) dengan judul Hubungan Antara Kehamilan Letak Sungsang Dengan Kejadian Ketuban Pecah Dini Di Ruang Bersalin RSUD Dr. Muh Soewandhi Kota Surabaya Tahun 2015 didapatkan hasil pengujian statistik menggunakan Spearman Rank menunjukkan ada hubungan antara kehamilan letak sungsang dengan kejadian ketuban pecah dini, $p$ value $(0,000)$ dimana $p$ value $<\alpha(0,05)$. Sehingga hipotesis yang menyatakan ada hubungan antara letak janin dengan kejadian ketuban pecah dini terbukti secara statistik.

Dari hasil penelitian, teori terkait dan penelitian terkait sejalan dengan penelitian yang saya lakukan di klinik alisa talang keramat kenten Palembang Tahun 2018 menunjukkan sebagian besar sampel mengalami letak sungsang dengan kejadian ketuban pecah dini. Hal ini terjadi karena kelainan letak janin merupakan suatu penyulit persalinan yang sering terjadi sebab keadaan atau posisi janin dalam rahim yang tidak sesuai dengan jalan lahir yang menyebabkan terjadinyaa ketidakteraturan bagian terendah janin untuk menutupi pintu atas panggul, serta mengurangi tekanan terhadap membran bagian bagian bawah dan bagian terendah ketuban langsung menerima tekanan intraurine yang dominan sehingga dapat menyebabkan ketuban pecah dini. Sehingga dapat disimpulkan bahwa ada hubungan antara letak janin dengan kejadian ketuban pecah dini.

\section{KESIMPULAN}

Dari hasil penelitian ialah ada hubungan yang bermakna antara kadar hemoglobin ibu dan letak janin dengan kejadian ketuban pecah dini di klinik alisa talang keramat kenten Palembang Tahun 2018.

\section{SARAN}

Diharapkan lebih menambah refrensi seperti buku-buku, sumber majalah kesehatan, jurnal kesehatan serta bahan-bahan lain yang menunjang dalam pembuatan karya tulis ilmiah guna meningkatkan ilmu penegetahuan dan dapat menambah wawasan tentang ketuban pecah dini.

\section{DAFTAR PUSTAKA}

BPS. 2015. Badan Pusat Statistik. Palembang : Badan Pusat Statistik 
Cunningham, G. 2005. Obstetri Williams Vol 1 Edisi 21. Jakarta : EGC

Huda, N. 2016. Faktor-Faktor Yang Mempengaruhi Ketuban Pecah Dini Di RS PKU Muhammadiyah Surakarta. Jurnal (Online)

Mansjoer, A, dkk. 2001. Kapita Selekta Kedokteran Jilid 1. Jakarta : Media Aesculapius

Manuaba, IGB. 2008. Gawat Darurat Obstetri Ginekologi dan Obstetri Ginekologi Sosial Untuk Profesi Bidan. Jakarta : EGC 2010. Ilmu Kebidanan Penyakit Kandungan Dan KB. Jakarta : EGC

Maria. 2007. Ketuban Pecah Dini Berhubungan Erat Dengan Persalinan Preterm dan Infeksi Intrapartum. Jakarta : CDK

Morgan, GHC. 2009. Obstetri Dan Ginekologi. Jakarta : EGC

Notoatmodjo, S. 2010. Metodologi Penelitian Kesehatan. Jakarta : Rineka Cipta 2012. Metodologi Penelitian

Kesehatan. Jakarta : Rineka Cipta

Nugroho, Taufan. 2012. OBSGYN untuk Kebidanan Dan keperawatan. Yogyakarta : Nuha Medika

Ritawati. 2009. Tesis: Hubungan Anemia Dengan

Kejadian Ketuban Pecah Dini Di Kabupaten Purwokerto. Yogyakarta : Fakultas Kedokteran Universitas Gajah Mada Yogyakarta

Saifuddin. 2009. Buku Acuan Nasional Pelayanan Kesehatan Maternal dan Neonatal. Jakarta : Yayasan Bina Pustaka Sarwono Prawirohardjo

Saryono. 2013. Metodologi Penelitian

Kebidanan. Jakarta : Nuha Medika

SDKI. 2012. Survey Demografi dan Kesehatan Indonesia. Jakarta : Badan Pusat Statistik

Sudarto. 2015. Anemia Terhadap Kejadian Ketuban Pecah Dini Pada Ibu Bersalin Di Pontianak. Jurnal Kebidanan Khatulistiwa, tahun 2015 Vo.1 No.2

Sumarah. 2008. Asuhan Kebidanan Pada Ibu Bersalin. Yogyakarta : Penerbit Fitramaya

Palembang, Dinkes. 2015. Profil Kesehatan Kota Palembang. Palembang : Dinas Kesehatan Kota Palembang ; 13

Prawirohardjo, S. 2007. Ilmu Kebidanan. Jakarta : Yayasan Bina Pustaka Sarwono Prawirohardjo 2009. Ilmu Kebidanan. Jakarta : Yayasan Bina Pustaka Sarwono Prawirohardjo
Varney, H. 2010. Buku Ajar Asuhan Kebidanan. Jakarta : EGC

WHO. World Health Organization. 2014. Maternal Mortality. WHO Media Center (Online) 
